\title{
INSTALLATIONS HYDROELECTRIQUES EN ECOSSE
}

Sir William HALCROW

Ancien Président de la British Institution of Civil Engineers

Cet article traite essentiellement de l'Energie Hydraulique en Ecosse ; toutefois, le lecteur comprendra que le sujet est ici considéré comme un des aspects du complexe et vaste problème de la structure sociale de la Grande-Bretagne. Aussi a-t-il semblé intéressant de faire un peu d'histoire et d'expliquer les origines de la situation économique actuelle, étudiée de ce point de vue particulier, plutôt que de se limiter à une simple description des ouvrages en construction ou en cours d'étude. A vrai dire, à notre époque, que caractérise une organisation poussée de la Société, il est presque impossible de procéder autrement, car l'importance des organisations individuelles s'amenuise progressivement.

Quand I" "Institution of Civil Engineers » fut fondée sous Charte Royale en 1828, elle prit comme définition du Génie Civil "L'art de maîtriser les grandes sources de puissance de la nature, pour l'usage et l'agrément de l'Homme». et l'on conçoit que TREDGOLD se soit rendu compte avec acuité, de l'importance de l'énergie hydraulique à l'époque où il avança cette définition. Même aujourd'hui, les restes de moulins à eau, dont certains datent de cinq cents ans nous montrent jusqu'à quel point la plupart de nos rivières des Midlands étaient devenues, sur des miles et des miles, un long chapelet de biefs de moulins. Cependant, à chaque époque correspond une conception particulière des grands ouvrages: bien vite, il devint évident que, à cette échelle, de telles sources d'énergie ne pouvaient suivre le rythme accéléré du développement industriel qui, par la découverte de la machine à vapeur, se mua bientôt en une "Révolution Industrielle ». L'insuffisance de ces installations ne provenait pas seulement de la roue hydraulique : elle résidait dans les conditions géographiques elles-mêmes qui n'ont pas permis de trouver des sites favorables suffisamment proches des centres industriels pour rendre possible un équipement hydraulique puissant. L'industrie se tourna donc vers une autre source d'énergie: comme chacun sait, tout notre développement industriel, toutes nos vues d'avenir furent basés sur l'extraction de charbon abondant et peu coûteux. C'est pourquoi, d'une part, nous ne ressentions guère le besoin d'équiper les ressources hydrauliques et, d'autre part, le coût du premier établissement d'un équipement hydraulique, plus élevé que celui d'une centrale à vapeur de puissance équivalente, constituait un handicap certain.

Il parut évident, dès cette époque, que la seule source importante d'énergie hydraulique de Grande-Bretagne était cette grande étendue montagneuse du Nord de l'Ecosse avec ses lacs et ses rivières; région si reculée, si pauvre en routes, dépeuplée par la guerre civile et par des conditions économiques défavorables, dépourvue de tout, sinon du plus modeste minimum de terre fertile, où seuls abondent la pluie et le mauvais temps. Ce Pays déshérité n'avait aucun attrait pour les industries établies alors dans le reste du Pays.

Les dernières années du $X \mid X^{0}$ siècle, cependant, mirent en jeu quelques nouveaux facteur.s Le premier fut le développement de l'électricité, qui révolutionna complètement le domaine de la force motrice et assouplit dans une certaine mesure la distribution de l'énergie; le second fut l'extension de l'industrie légère, qui contribua si puissamment à l'amélioration générale de conditions d'existence encore bien primitives; un troisième facteur fut la production et l'utili. sation commerciale des métaux légers. C'est pré. cisément l'industrie naissante de l'aluminium qui se tourna vers les montagnes de l'Ecosse (Les Highlands) pour trouver l'énergie électrique abondante et bon marché dont elle avait besoin.

C'est à FOYERS, dans le Great Clen, que fut installée en 1897 une première usine d'aluminium, suivie de l'usine de Kinlochleven en 1910 , et finalement par celles du Lochaber (1), dont la

(1) Voir Frontispice. 
construction se poursuivit, par étapes successives, pendant de nombreuses années ; la dernière installation n'a été terminée qu'en 1944. L'Auteur a été étroitement associé à cette œuvre, entre-

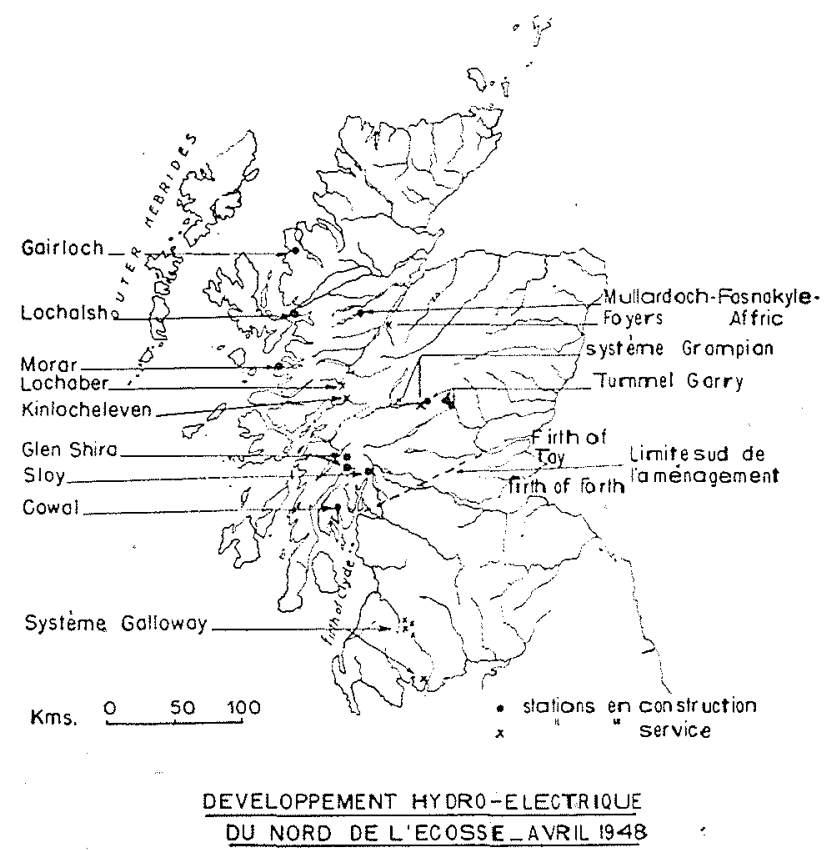

prise pour le compte de la British Aluminium C Ltd ; la puissance installée dépasse actuellement 100.000 KW. Le facteur d'utilisation est éleve. car les fours à aluminium demandent la fourniture ininterrompue de courant continu; la production totale annuelle d'énergie est importante.

Quoique des centrales de grande puissance ou des conduites de grande taille ne soient pas nécessaires pour satisfaire aux exigences particulières des usines d'aluminium, celles-ci soulèvent plusieurs problèmes d'exploitation difficiles. C'est ainsi que l'arrêt d'un four est une opération qu'on n'engage pas à la légère, et le temps maximum pendant lequel, en pratique, on peut couper l'alımentation d'un four chargé, ne dépasse pas quelques heures. Au delà de ce temps, le métal fondu se solidifie et le déchargement d'un creuset froid est une opération très difficile. L'alimentation ininterrompue des machines et des conduites pose donc un problème qui nécessite une mise au point très minutieuse.

En plus de ces usines destinées à l'Electrométallurgie, un autre ensemble de centrales destiné à l'alimentation du réseau d'interconnection de l'Ecosse centrale et à la fourniture d'énergie aux lignes locales, fut installé avant la seconde guerre mondiale. Cet ensemble est connu sous le nom de "Crampian Scheme»; il est situé dans la partie Sud-Est des Highlands; sa puissance totale installée est de $85.000 \mathrm{KW}$ répartis entre plusieurs centrales. Un autre ensemble, connu sous le nom de Galloway Scheme, fut ensuite construit vers 1930 dans le Sud-Ouest de

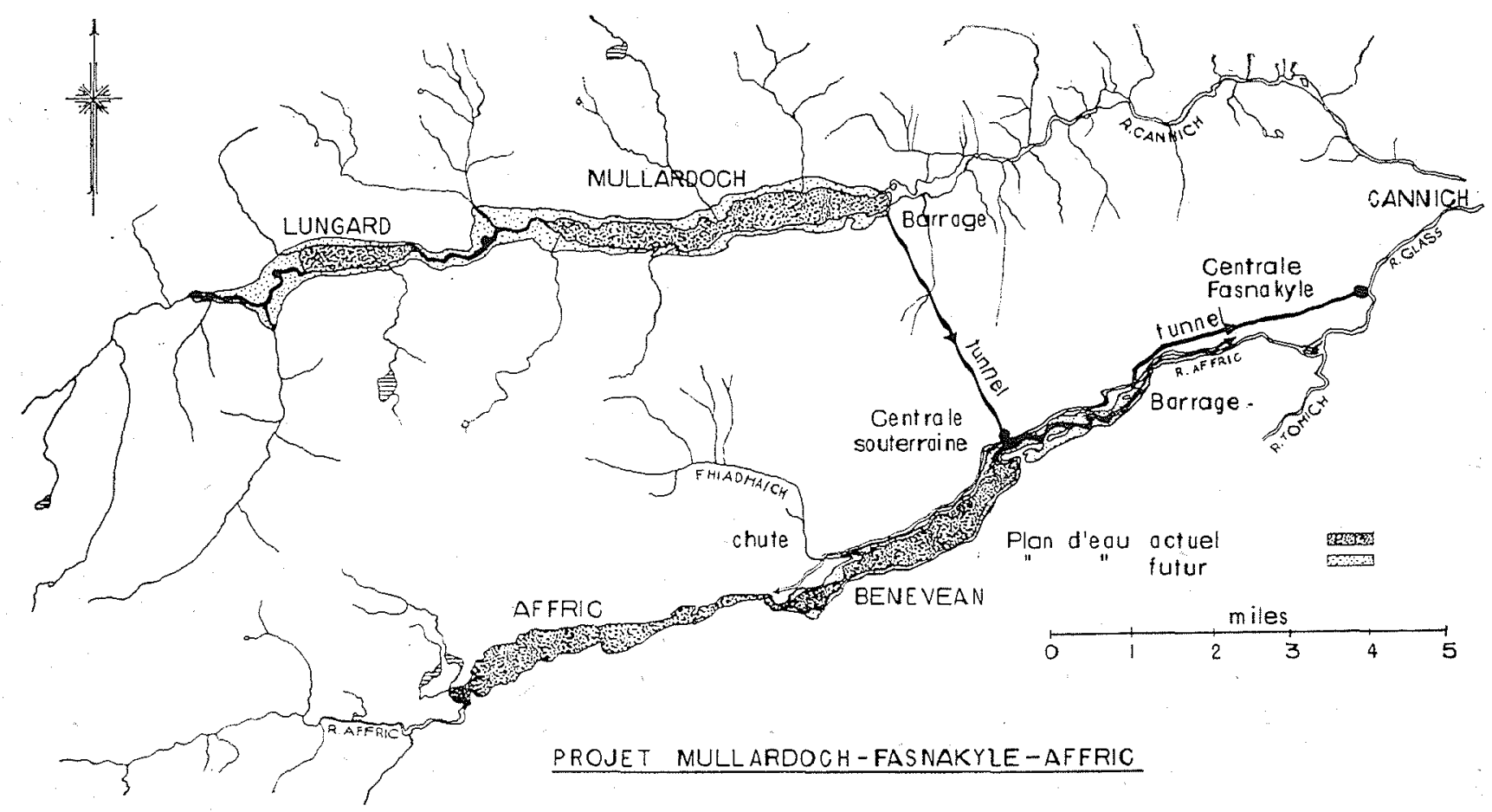


l'Ecosse ; il est principalement destiné à assurer la fourniture aux heures de pointe, sur les grands réseaux industriels du Nord-Ouest de l'Angleterre et du centre de l'Ecosse. Le coefficient d'utilisation est de $20 \%$ environ, pour une puissance installée de $102.000 \mathrm{KW}$, répartis en cing centrales. Enfin, un autre ensemble plus modeste a été réalisé dans le centre de l'Ecosse: les centrales de la vallée de la Clyde.

Un certain nombre d'autres projets ont été étudiés entre les deux guerres, concernant les centrales situées dans les Highlands; on peut citer le «Caledonian Scheme » destiné à la production de carbure de calcium, et les groupes "Affric» et «Farrar», destinés à la fourniture d'énergie pour la distribution générale et l'interconnection; pour des raisons politiques, ces projets ne furent pas approuvés par le Parlement.

Pour que la construction d'ouvrages impor tants de cette nature puisse être entreprise, il est nécessaire, comme le lecteur peut le voir, que les groupements d'intérêts qui sont en cause, déposenl un projet de loi particulier devant le Parlement. Si ce projet rencontre une forte opposition, une enquête spéciale est menée; qu'un de ces projets, présenté sous diverses formes n'ait pas été rejeté moins de quatre fois en quelque douze ans, avant la dernière guerre, cela montre que l'extension des installations hydrauliques des Highlands soulevait des problèmes assez particuliers. II est inutile de commenter longuement ce fait, sinon pour dire que l'opinion écossaise était alors assez montée, et que l'on sembla se trouver dans une impasse.

C'est dans ces circonstances difficiles que le Secrétaire d'Etat aux Affaires Ecossaises chargea un comité, sous la direction de Lord COOPER, de dire s'il était pratiquement possible et s'il était désirable de pousser plus loin l'équipement hydraulique du Nord de l'Ecosse. Un effet tangible des délibérations du Comité, fut la loi de 1943 sur l'équipement hydroélectrique de l'Ecosse. Cette loi confia à un nouvel organisme, le "North of Scotland Hydro-Electric Board», la réalisation de toutes les installations hydroélectriques dans les Highlands et dans les îles côtières. Une loi approuvée en 1947, l'ElectricityAct, étendit le domaine d'action de cet organisme aux territoires situés au Nord d'une ligne droite joignant la Clyde à la Tay; cette limite est tracée sur la carte, fig. 1.

Une des premières décisions du «North of Scotland Hydro-Electric Board » fut la nomina- tion d'un comité d'ingénieurs hydroélectriciens expérimentés, parmi lesquels s'est trouvé l'Auteur. Ce Comité prospecta les ressources hydrauliques existant en puissance dans sa zone d'action, et à la suite de ses études, une liste de 102 installations possibles fut dressée. La production totale de ces installations peut être évaluée à 6 milliards de KWh par an, ce qui représente un septième de la production totale annuelle de la Grande-Bretagne.

De nouvelles industries seront probablement attirées par les disponibilités hydroélectriques des Highlands, mais la quantité d'énergie citée plus haut dépasse de beaucoup les besoins locaux et l'assiette économique de ce programme réside certainement dans l'exportation d'énergie vers la région industrielle du centre de l'Ecosse.

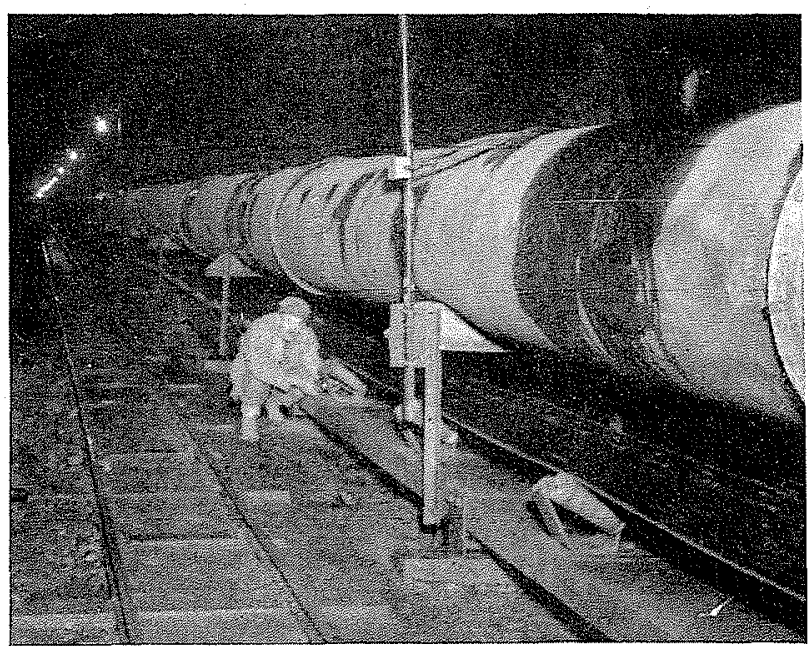

TUNNEL DE CLUNIE

Vue générale du tunnel en fer à cheval de 24 pieds de diamètre

La première tâche du «North of Scotland Hydro-Electric Board » est de participer au relèvement du Pays des Highlands, qui a subi, au cours des deux siècles passés, la grande émigration qui a suivi la révolte de 1745, puis l'abandon progressif de la population restante, fuyant un pays pauvre, attirée par les conditions de vie meilleures que leur promettait le reste de la Grande-Bretagne. Pour reprendre les termes mêmes d'un rapport du «Board», on espère que l'électrification locale aura pour effets de « créer des conditions favorables à l'installation de nou velles industries, de créer du travail, de fonder de nouvelles agglomérations, d'améliorer les conditions de logement, en un mot de stimuler sous 


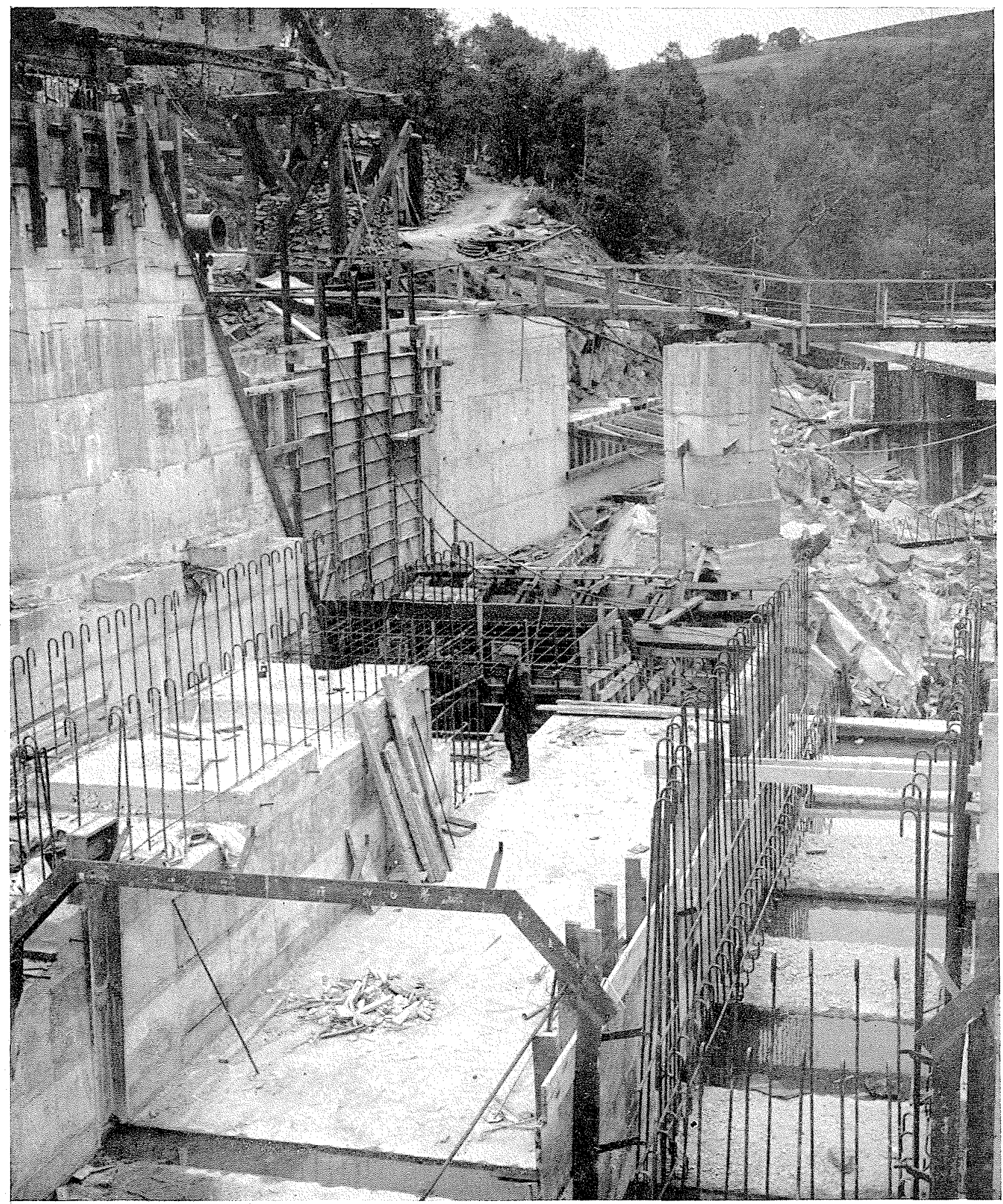

Barrage de Clunie en conștruction 
tous ses aspects la vie dans la région des "Highlands».

II est prévu d'utiliser le produit de la vente de l'énergie électrique fournie aux réseaux d'interconnection par plusieurs centrales de grande puissance, à financer la construction et I'exploitation d'un certain nombre de petites centrales qui, prises individuellement, pourraient n'être pas rentables. Il a, en effet, été avancé avec beaucoup de bon sens, que certaines de ces petites centrales, même si l'énergie ne coútait rien à la production, ne seraient pas rentables en raison du coût de la distribution aux usagers éventuels habitant une région dont la population est si clairsemée.

Au cours des quelques années qui ont suivi la guerre, 13 projets d'installation pour la production et l'exportation d'énergie électrique ont reçu l'approbation du Parlement ; un plus grand nombre sont en cours d'étude. Certains d'entre eux comprennent plusieurs ensembles d'instal lations hydroélectriques, dont chacun peut comprendre à son tour plusieurs centrales.

Lorsquiun projet a reçu l'approbation du ParIement, les études de détail sont exécutées par l'un des ingénieurs-conseils du «Hydro-Electric Board » ou sous sa direction. Parmi les installations en cours de construction, les principales sont Ies suivantes:

\begin{tabular}{|c|c|}
\hline Installations & $\begin{array}{c}\text { Puissance installée } \\
\text { KW. }\end{array}$ \\
\hline Tummel-Garry & $147.000 \mathrm{KW}$ \\
\hline Loch Sloy . . . . . . . . . . . & $130.000 \mathrm{KW}$ \\
\hline Mullardoch-Fasnakyle-Affric & $66.000 \mathrm{KW}$ \\
\hline Glen Shira $\ldots \ldots \ldots \ldots$ & $24.000 \mathrm{~kW}$. \\
\hline Cowal $\ldots$ & $6.000 \mathrm{KW}$ \\
\hline
\end{tabular}

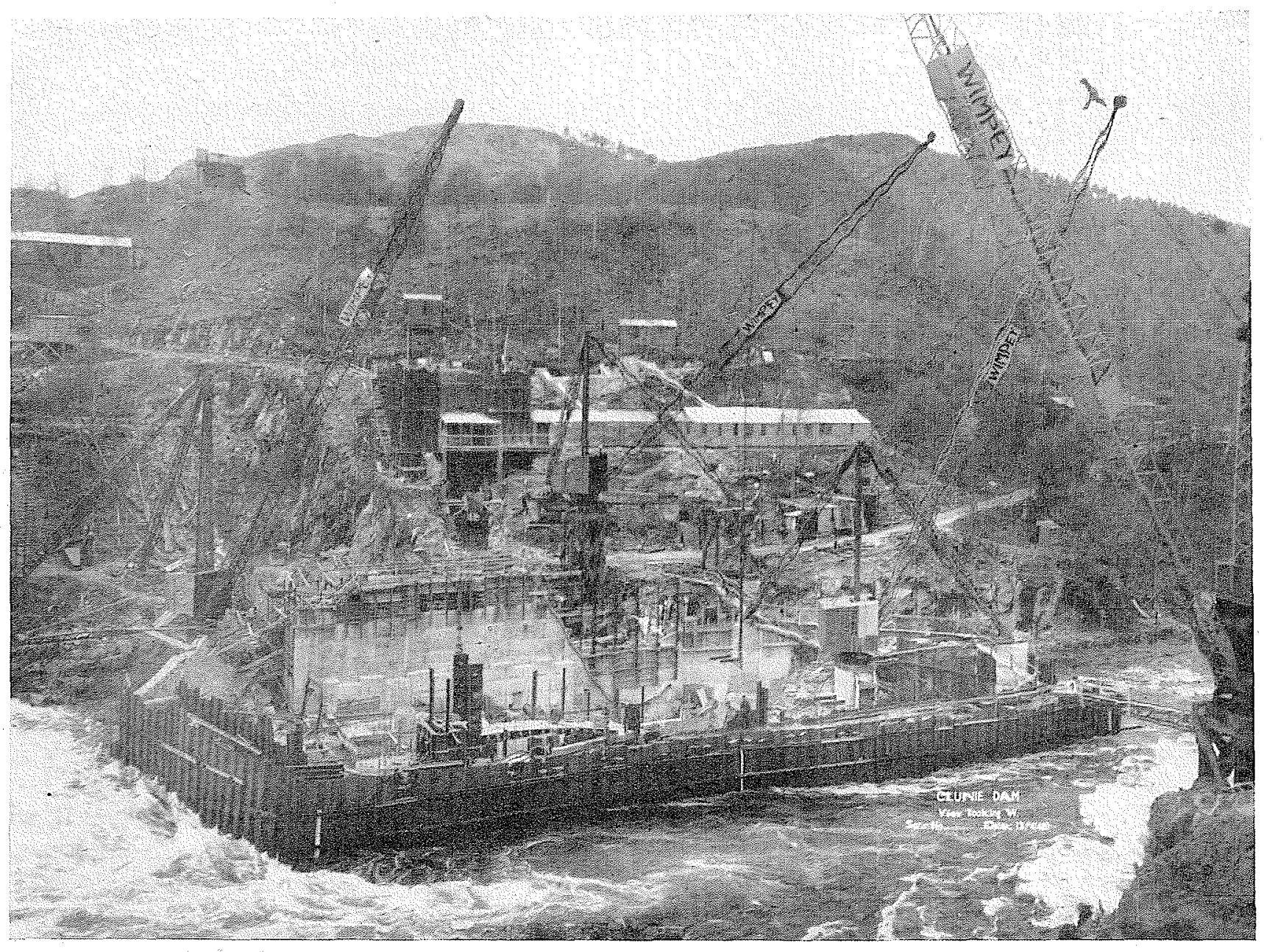


D'autres chantiers sont en préparation et vont bientôt être ouverts. La liste ci-dessus passe sous silence un certain nombre d'installations d'intérêt local qui sont également en construction, par exemple celles de LOCH MORAR, de LOCHALSH et de CAIRLOCH.

On notera que les facteurs d'utilisation pour lesquels ces centrales sont prévues varient d'un cas à l'autre, si bien que la production totale annuelle ne correspond pas à la répartition des puissances qu'indique la liste ci-dessus.

Les installations hydroélectriques des Highlands fonctionnent dans l'ensemble sous des hauteurs de chute moyennes et comportent une excellente régularisation, grâce aux réservoirs d'accumulation qui ont dû être aménagés dans beaucoup de lacs naturels. Les barrages sont généralement du type gravité ou du type à con- tre-forts: l'érosion de l'époque glaciaire n'a, en effet, laissé subsister que peu de sites favorables à la construction de barrages-voûte.

Le montant total des marchés déjà passés, tant pour le Génie Civil que pour le matériel et les lignes, s'élève à 18 millions de Livres sterling (1.550.000.000 de francs)

On comprend aisément que l'équipement hydroélectrique n'ait pu faire un tel bond en avant que grâce au rétablissement de la confiance dans les relations entre les intérêts écossais et les autorités chargées de faire aboutir les projets. Un facteur important de l'économie des Highlands réside actuellement dans la pêche, soit sportive, soit commerciale: truite et saumon abondent dans la plupart des cours d'eau. La location de sections riveraines aux sportsmen pendant la saison de la pêche rapporte des som-

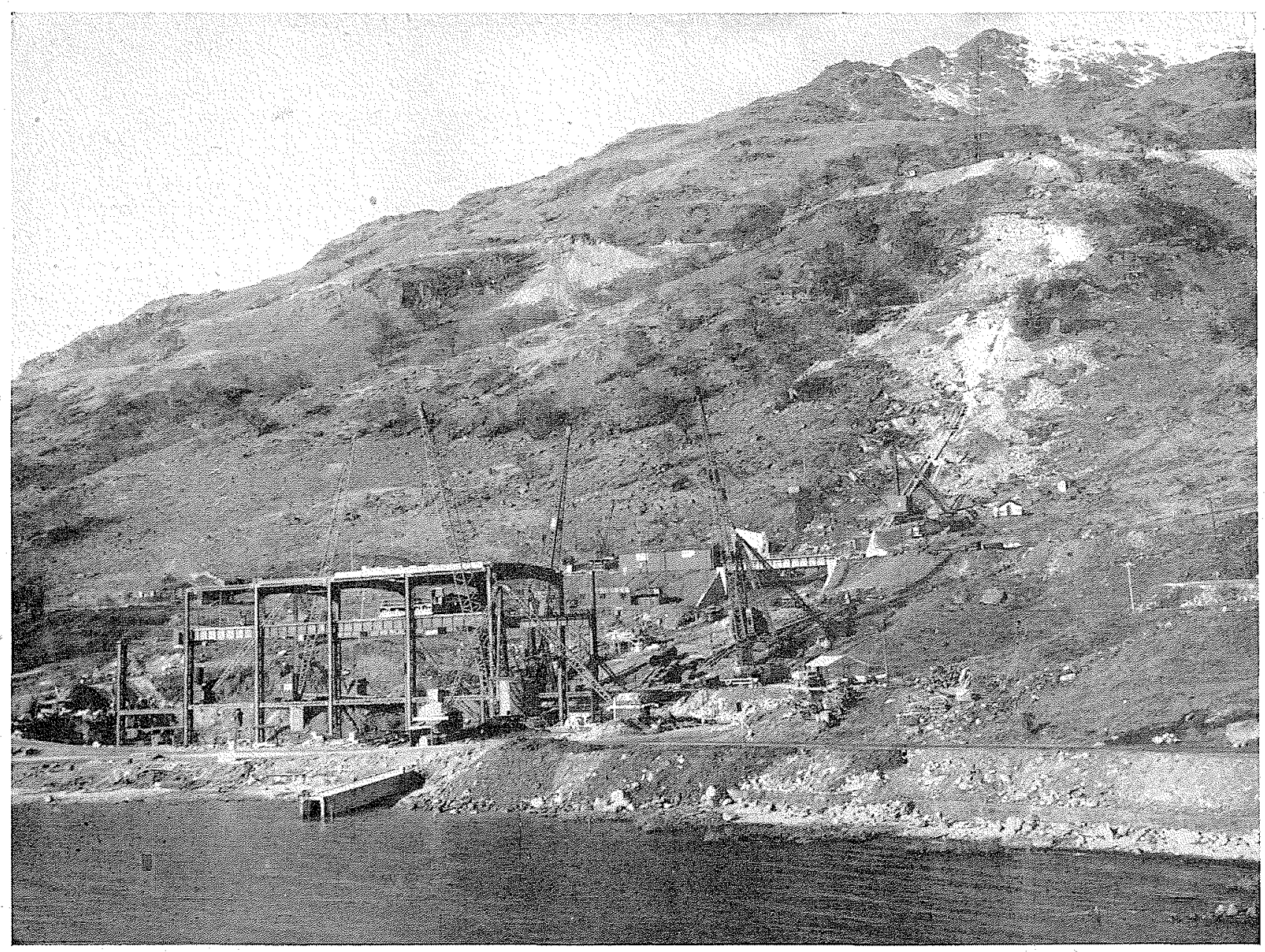

Equipement de Loch Sloy - Emplacement de la Centrale 


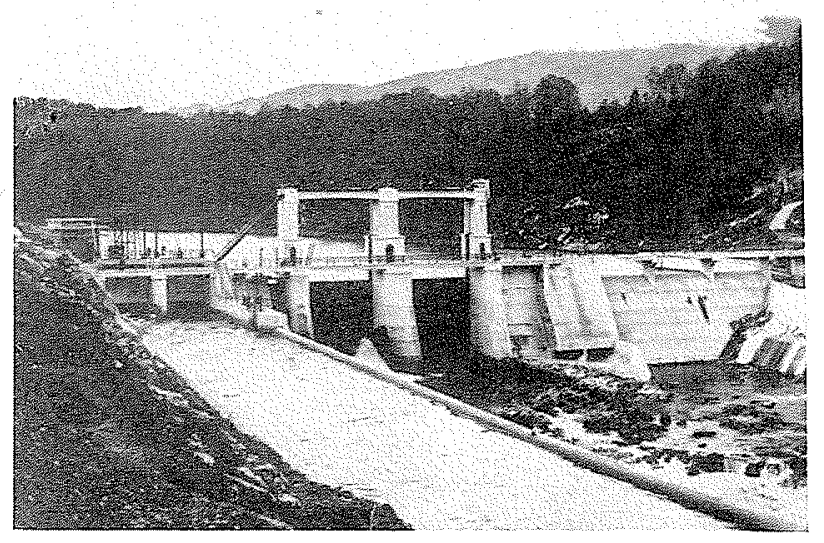

Barrage de Dunalistair de la Grampian Electricity Supply Co

mes importantes ; d'autre part, un nombre considérable de touristes affluent vers des sites qui comptent parmi les plus sauvages du monde. II n'est pas besoin d'insister sur les répercussions que l'équipement hydraulique peut exercer dans ces deux domaines; le Secrétaire d'Etat aux Affaires d'Ecosse a d'ailleurs, afin de réduire les frictions, chargé deux comités, composés de personnalités Ecossaises indépendantes, de s'occuper de la conservation des sites et des pêcheries.

Le comité des pêcheries estime la valeur poissonnière de chaque cours d'eau touché par les installations hydroélectriques; lorsqu'un projet est approuvé, il fixe le débit de restitution qui doit être assuré et les dimensions des échelles à poissons. Dans certains cas, on a dú établir des

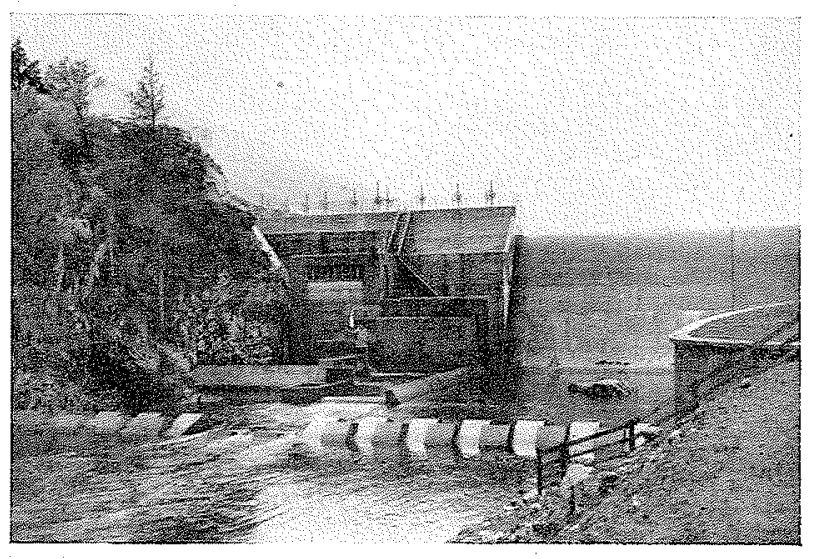

Equipement de Lochaber

Barrage de Spey montrant l'évacuation de crues, la chambre de manoeuvre et l'échelle à poissons

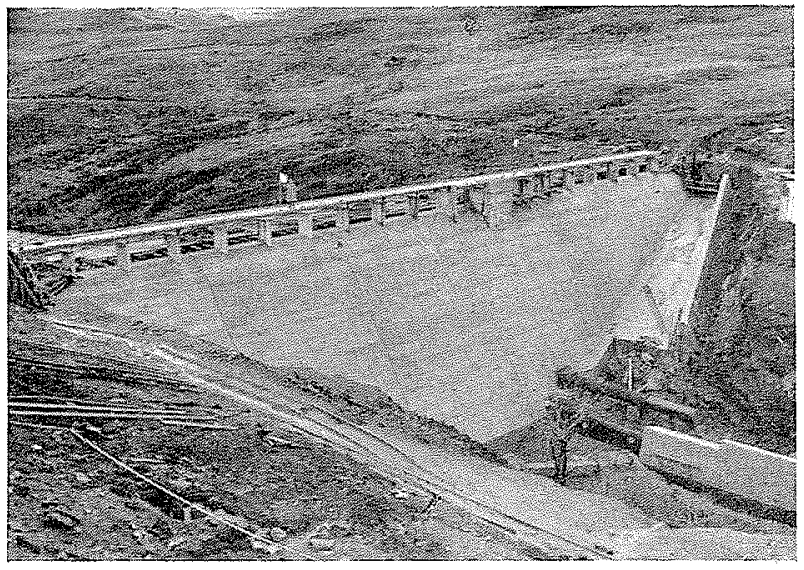

North of Scotland Hydro-Electric Board Barrage Allt Gleann Udalain - Vue générale

viviers pour le frai et l'élevage, afin d'éviter la disparition du poisson.

Le Comité des sites, d'autre part, a pour souci de réduire au minimum l'effet des constructions nouvelles sur le paysage; il s'attache en particulier à la conservation des sites remarquables. Dans certains cas, la tranche d'eau utilisable dans les réservoirs a été strictement limitée, afin d'éviter de découvrir périodiquement des berges boueuses, d'un aspect désagréable; dans d'autres cas, c'est une cascade que l'on a imposé d'alimenter à partir d'un réservoir situé à l'amont. Il arrive que la quantité d'eau distraite dans ce but, ou pour la pêche, représente une partie importante du débit naturel. Les conduites et les cônes de déblais doivent être cachés s'ils risquent de nuire à l'harmonie du paysage. Tous les barrages, tous les bâtiments doivent être traités par des architectes écossais et des dessins perspeçtifs sont communiqués au public avant de passer aux plans d'exécution. Il convient de reconnaître, malgré tout, que le style des constructions laisse apparaître un certain eclectisme, mais cela est peut-être difficilement évitable.

L'auteur espère que cet article permettra de comprendre plus clairement la transformation profonde qui affecte l'histoire économique de l'Ecosse. Les travaux se poursuivent au milieu de maintes difficultés, difficultés de transport, manque de main-d'œuvre et de logements, manque de matériaux, climat rude. On peut cependant escompter que les nouvelles centrales commenceront à fournir de l'énergie en 1949, et que leur production s'accroîtra ensuite pendant de nombreuses années. 


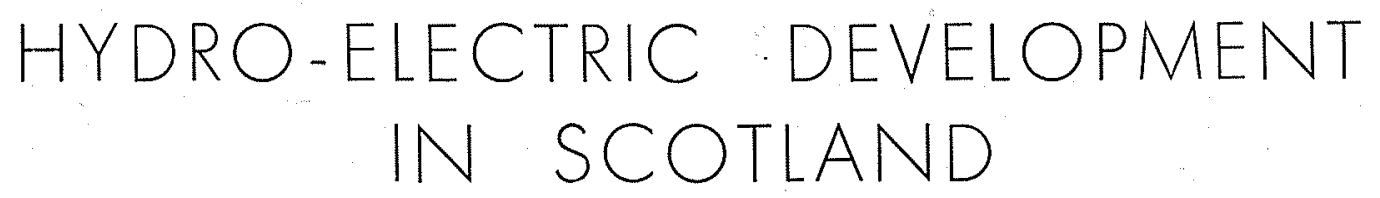

Sir William HALCROW

Past-President of the Institution of Civil Engineers

Although the specific subject of this article is water power in Scotland, readers will realise that hydro-electric development there, is one facet of a large and complex British Social Structure. It may therefore be of more value to describe a little of the history and present day economic setting of this particular story rather than to limit it to a description of schemes either under construction or under consideration. Indeed in these days of highly organised societies it is almost impossible to do otherwise as the significance of individual developments progressively lessens.

When the Institution of Civil Engineers received its Royal Charter in 1828, it chose as the definition of civil engineering "The art of directing the great sources of power in nature for the use and convenience of Man » and one may conceive that TREDCOLD was acutely aware of the great importance of power from water wheels at the time he put it forward. Even to-day the remains of water mills, some of them as much as 500 years old, show how several of our Midland rivers became one long succession of mill ponds for miles on end. However, each era has its own standards of greatness and it soon became evident that power supplies of this nature were insufficient for the growing pace of industrial development which, under the stimulus of the steam engine, became known as the Industrial Revolution. The insufficiency was not solely that of the water wheel in itself but lay in the absence of geographical conditions near enough to existing centres of industry which would have allowed a large water power development. Industry therefore, turned to other sources of power and, as is well known, our whole industrial development and outlook was based on what was an abundant and cheap supply of coal. There was in consequence little urge to develop existing water power resources and, in addition, the high initial cost of a water power scheme as compa- red with equivalent steam plant was no doubt a deterrent.

It was of course obvious even then, that the only major source of water power in Great Bri. tain was that great area of mountain, stream and lake lying in the northern part of Scotland, but a region of such remoteness, so poorly provided with roads, denuded of population by civil wai and economic conditions, lacking all but the barest minimum of fertile land, and abundant only in rain and bad weather, had no attraction for the industries then established in the rest of the country.

The later years of the 19th Century, however, brought several new factors into the situation. The first was the development of electrical power which completely revolutionised the use of prime movers and allowed power to be distributed with relative ease. A second was the initial development of light industries which did so much to overcome the general primitive conditions of life, and a third was the beginning of the commercial usage and production of the light metals. From this latter group, it was the young aluminium industry which turned to the Scottish Highlands for the abundant supply of cheap electricity which it required.

The production of aluminium was started in the Great Glen at Foyers in 1897, followed by the plant at Kinlochleven in 1910, and finally by the Lochaber Scheme, the development of which stretched in stages over several years, and its latest extension was completed only in 1944. The author has been intimarely connected with this work for the British Aluminium Company Limited and the total installed capacity is now more than $100,000 \mathrm{KW}$. The operational load factor is high since aluminium furnaces require power as a continuous direct current and the total annual output of energy is large.

Although plant capacity and size of conduits 
need not therefore be unduly large to meet the specific requirements of an aluminium plant, several difficult operational problems arise. For example, the closing down of a furnace is a major operation and the practical limit of time for which a charged crucible may be starved of power is only a few hours. After this time the molten material solidifies and great difficulty is experienced in digging it out. The maintenance of machines and conduits is, therefore, a problem which requires an extreme nicety of organisation.

In addition to the above mentioned aluminium schemes, a development for bulk supply to the Central Scotland grid and for general local supply, known as the Grampian Scheme, was carried out before the second World War in the Central and South Eastern areas of the Highlands and the installed capacity totals some 85,000 $\mathrm{K.W}$. in several generating stations. A further development known as the Galloway Scheme was constructed in the South West of Scotland in the 1930's, whose main function is for peak load supply to the great industrial areas of North West England and Central Scotland. The load factor is low at approximately $20 \%$ while the plant capacity is $102,000 \mathrm{~K} . \mathrm{W}$. spread over five generating stations. Finally there was a small scheme in Central Scotland known as the Clyde Valley development

A number of other proposals were made between the wars for power schemes in the Highlands as for example the Caledonian Scheme for the production of calcium carbide and the Affric and Farrar Schemes for general public utility and power export, but these schemes were rejected by Parliament for political reasons. As readers may be aware, the construction of large works of this nature requires the promotion of a specific Bill in Parliament by the interests concerned. If opposition to the measure is considerable a special enquiry is held and when it is understood that one of these schemes in various forms was rejected no less than four times in some 12 years before the last war, it will be realised that a somewhat peculiar situation had arisen in the development of Highland Water Power. There is no advantage in saying more than that Scottish feeling ran high and an impasse appeared to have been reached.

It was in these inauspicious circumstances that the Secretary of State for Scotland set up Lord Cooper's Committee to consider the practicability and desirability of future development of water power in the North of Scotland. The tangible result of this Committee's deliberation was the Hydro-Electric Development (Scotland) Act of 1943 under which the North of Scotland Hydro-Electric Board was set up to carry out all hydro-electric development in the Highlands and in the islands fringing the coast. By the Electricity Act of 1947, the area of this Board's authority has been extended to cover the whole of the region North of a line drawn from the River Clyde to the River Tay as shown on the accommpanying diagram.

One of the first actions of the Board was to appoint a panel of experienced hydro-electric engineers, of whom the author was one, to examine the potential water power resources of the area and as a result of this investigation a total of some 102 potential schemes was listed for examination. The estimated total output of these schemes was more than 6000 million K.W.h's of electricity per annum, i.e., about one seventh of the electrical energy generated in Great Britain in a year.

While some new industries may be attracted to the Highlands when hydro-electric power is available, this amount of power is much greater than could be used locally and the major economic basis of the Board's programme is to export energy to the industrial area of Central Scotland.

The primary function of the Board is to assist in the rehabilitation of the Highlands where the past 200 years have seen the great depopulation following the «1745» Rebellion and the gradual drift of much of the remaining population from a naturally poor land to the improved standards of living possible in other parts of Great Britain. In the words of the Board, the distribution of electrical power locally is hoped to result in "Opportunity for new industries; the provision of new jobs ; the creating of new communities ; the improvement of housing conditions; and the stimulation of all phases of life in the Highland area. 》)

It is intended that the profits resulting from bulk exports of power from several large schemes shall be used to subsidise the construction and operation of a number of small local schemes which might be quite uneconomic in themselves. Indeed it has been said with considerable reason for some of these small projects that, even if the power was produced at no cost at all, it would still be uneconomic to transmit it to potential users in such a sparsely populated countryside. 
In the few years since the end of the war some 13 Constructional Schemes for generation and transmission of electrical power have received Parliamentary approval while many more are in course of preparation. Several of these Constructional Schemes contain more than one hydroelectric project which in itself may include inore than one generating station.

After a scheme has been approved by Parlia. ment the detailed design is carried out by or under the supervision of one of the Hydro-Electric Board's Consulting Engineers and the following major projects are actually under construction while others are approaching the construction stage.

\begin{tabular}{|c|c|}
\hline Scheme & Plant Capacity \\
\hline Tummel-Garry & 147,000 K.W. \\
\hline Loch Sloy . . . . . . . . . . . . . & 130,000 K.W. \\
\hline Mullardoch-Fasnakyle-Affric & 66,000 K.W. \\
\hline Glen Shira ............ & 24,000 K.W. \\
\hline Cowal .... & 6,000 K.W. \\
\hline
\end{tabular}

A number of small local schemes are also under construction, e.g. those at Loch Morar, Lochalsh and Gairloch.

Again it should be pointed out that the schemes are designed for different load factors and the total annual output does not follow the sequence given in the Table above.

Hydro-electric schemes in the Highlands are generally characterised by medium heads with a high degree of utilization of water by the storage available in many of the natural lakes. Dams are usually of the gravity or buttress type as the Ice Age has left few sites suitable for arch dams.

Contracts already placed for civil engineering works, plant and transmission amount to some £18 million (1,550 million francs).

It will be realised, of course, that this great surge of hydro-electric development would not have been possible without a re-establishment of a measure of confidence between local Scottish interests and the developing authority. Large factors in present day Highland economy are fishing for sport and commerce since many of the streams are rich in salmon and trout. Large sums are derived from the renting of stretches of bank to sportsmen during the season and there is also a considerable tourist traffic attracted by some of the most striking scenery in the world. The effect of hydro-electric developments on these two interests needs no amplification and in order to minimise friction the Secretary of State for Scotland set up two committees to deal with Amenity and Fisheries, composed of independent and authoritative Scotsmen. The Fisheries Committee assesses the fishing value of any stream considered for hydro-electric development and lays down the amount of compensation water to be discharged from the reservoirs and the size of fish passes if development is allowed at all. In some cases the provision of new spawning beds or hatcheries is required to maintain fish life in the stream.

The Amenity Committee on the other hand, is concerned with minimising the effect on the countryside of new construction and the preservation of beauty spots is an important consideration. In some cases the size of reservoirs is rigidly limited to avoid the periodical exposure of areas of unsightly muddy foreshore. Again water may have to be discharged from reservoirs to maintain a waterfall further downstream and indeed in some cases the amount of water necessary for this purpose and for fishing is a great proportion of the natural runoff. Pipe lines and spoil tips have to be concealed if any exposure is likely to offend. All dams and buildings have to receive architectural treatment by Scottish architects and perspective drawings are made available to the public before a project passes the Constructional Scheme stage. It must be stated, however, that a certain eclecticism of style is apparent but this is perhaps inevitable in such work.

It is hoped that this article will give readers a clearer picture of what is a considerable economic development in the history of Scotland. The work is proceeding under many difficulties, such as poor access, shortage of labour and accommodation, shortage of materials and a severe climate. It is expected, however, that the first power supply from the new schemes will be available in 1949 and will increase thereafter for many years. 